\title{
Swedish students protest proposal to cut PhD terms
}

In an effort to synchronize its educational system with the rest of Europe, Sweden on 22 February passed an educational reform that includes a contentious measure to limit funding for $\mathrm{PhD}$ programs.

The law will help bring Sweden in line with the Bologna Process, a scheme that aims to harmonize by 2010 higher education among 45 countries in Europe. But critics in Sweden say the measures could weaken educational standards and jeopardize employment prospects for graduate students seeking competitive postdoctoral positions in the US and elsewhere.

Launched in 1999, the goal of the Bologna Process is to promote uniform educational standards and ease mobility of students among the member countries, which now have an uneven hodgepodge of educational structures largely impenetrable to outsiders.

The first two phases of the scheme recommend that undergraduate programs throughout Europe should last three years and master's degree programs two years. The recommendations are not legally binding, but many countries such as Sweden and Germany are already converting to this system. Many Eastern European countries are particularly keen on the scheme, which could boost their weak higher-education systems.

"The Bologna Process is a great impetus for reforms," says Carsten Dose, a member of the German Science Council, a higher-education think tank in Berlin. But it's important that the system retains some flexibility, Dose says. For instance, some students need more time than others to prepare for an academic career.

The $\mathrm{PhD}$ phase of the Bologna Process has just begun and recommendations are expected to be complete in time for a summit in London in May 2007. At a May 2005 meeting in Norway, representatives of several governments agreed that most countries should have $\mathrm{PhD}$ programs that last three or four years, but they cautioned against overregulation, says Elizabeth
Tapper, a spokeswoman for the European University Association in Brussels. The association and a few others have been charged with developing recommendations.

Sweden's new law reflects the guidelines for the length of undergraduate and master's degree programs, and those met with little opposition. But several student groups in Sweden have protested the cut in $\mathrm{PhD}$ funding, which lops a year of university salary support for students with master's degrees down to three years from the current four.

The funding cut reflects growing pressure throughout Europe to get graduate students out of school swiftly, says Niclas Sigholm, president of the Swedish National Union of Students. Truncating PhD programs might actually make Sweden's graduates less competitive in the US, Sigholm says. "If you take away a year from our education, our contribution to the scientific community is going to decline."

Charlotte Schubert, Washington, DC

\section{US drug approval ignores science's subtleties, experts say}

A multiple sclerosis drug yanked off the market last year is on track to return, prompting some experts to say it should perhaps not have been withdrawn in the first place.

A US Food and Drug Administration (FDA) advisory panel in March voted unanimously to allow the drug, Tysabri, back on the market with some restrictions. Their decision followed a two-day meeting at which people who had benefited from the drug tearfully testified that the treatment was their only hope.

Tysabri launched in November 2004 after a fast-track approval from the FDA. Three months later, the drug's makers, Elan and Biogen Idec, withdrew it after discovering that a rare brain infection called progressive multifocal leukoencephalopathy (PML) had struck two people and killed one.

Experts say the abrupt halt and return to market demonstrates a need for less drastic reactions when the FDA first learns of serious side effects.

"The FDA has really got to have more alternatives than just an on-off switch," says Raymond Woosley, president of The Critical Path Institute, an independent institute that evaluates the drug approval process. "[The system] ignores the realities of science."

Once a treatment is on the market, the FDA cannot pull it off the shelves unless the information on its label is fraudulent. But

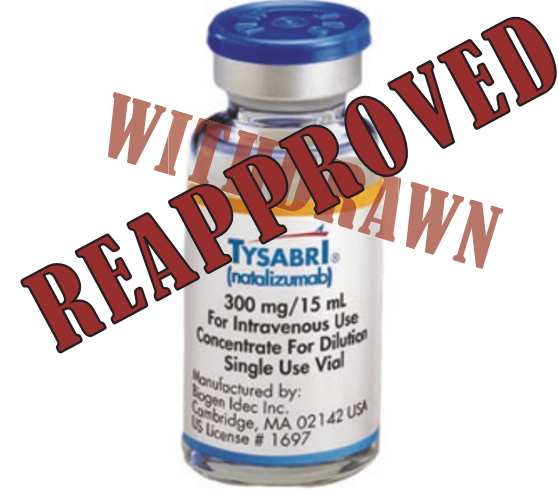

Once and again: Withdrawn in February 2005, Tysabri is likely to return to the market.

the agency can use its power to persuade a company to withdraw it. About three percent of approved drugs are withdrawn after release, but only one drug-Lotronex for irritable bowel syndrome-has previously been returned to the market.

Following Tysabri's withdrawal, the FDA also halted clinical tests of at least one other drug in its class-GlaxoSmithKline's 683699, which was in phase 2 trials. Officials at the FDA would not comment on the status of the other drugs in development.

Scientists had warned more than ten years earlier that those who take Tysabri or others in its class may be at risk for infection (Nat.
Med. 11, 359; 2005). Tysabri works by blocking immune cells called lymphocytes from entering the central nervous system-a mechanism that may also weaken the immune system.

A study conducted after the companies withdrew the treatment showed that the risk of developing PML is 1 in 1,000 (N. Engl. J. Med. 354, 924; 2006). Other studies on the drug's efficacy were also incomplete at the time of the withdrawal.

Still, the FDA and the companies had to take some sort of action to show the public that they are committed to safety, says David Feigal, former director of the FDA's Center for Devices and Radiological Health.

"Nobody knew the scope of the problem," adds Karl Kieburtz, chairman of the advisory panel and a professor of neurology at the University of Rochester. "In the absence of information you have to act on the principle of 'do no harm."”

As a condition for reapproval, the advisory committee recommended that Tysabri not be used along with other multiple sclerosis drugs. The panel also said that everyone who takes Tysabri must be registered and that they can only receive the treatment at authorized centers. As of 21 March, FDA officials had not yet announced their decision to allow the drug back on the market, but are expected to follow the committee's advice.

Emily Waltz, New York 